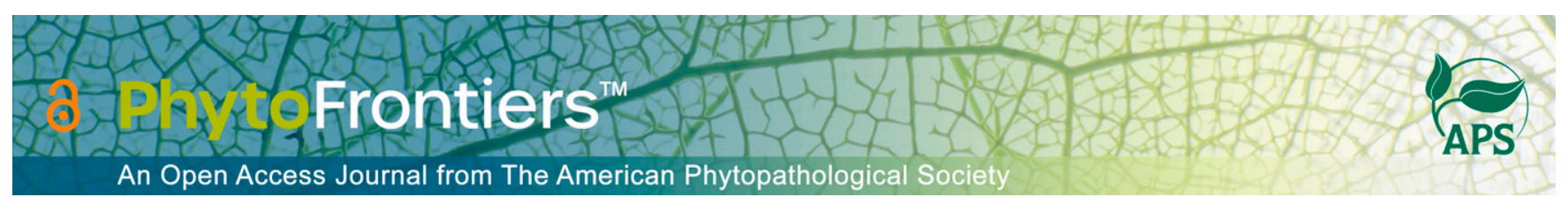

\title{
Research
}

\section{Detection of Nematophagous Fungi from Heterodera schachtii Females Using a Baiting Experiment with Soils Cropped to Brassica Species from California's Central Coast}

Ying-Yu Chen ${ }^{1}$ | Steven T. Koike ${ }^{2}$ | Geoffrey D. Logan ${ }^{3} \mid$ Christopher Drozd $^{3} \mid$ Juliana De Oliveira Silva ${ }^{1}$ | Nicole B. Colindres ${ }^{3} \mid$ Beth B. Peacock ${ }^{3} \mid$ Jennifer Smith Becker ${ }^{1} \mid$ Angelo Loffredo ${ }^{1}$ | Haiyan $\mathrm{Wu}^{4}$ | Paul M. Ruegger ${ }^{3} \mid$ J. Ole Becker ${ }^{1,+}$ (i) | James Borneman ${ }^{3,+}$ (i) |

${ }^{1}$ Department of Nematology, University of California, Riverside, CA 92521, U.S.A.

2 TriCal Diagnostics, Gilroy, CA 95020, U.S.A.

${ }^{3}$ Department of Microbiology and Plant Pathology, University of California, Riverside, CA 92521, U.S.A.

${ }^{4}$ Agricultural College of Guangxi University, Nanning 530004, China

† Corresponding authors: J. O. Becker; obecker@ ucr.edu and J. Borneman; borneman@ucr.edu

Accepted for publication 3 September 2020.

\section{Funding}

This project was supported in part by the University of California Agriculture and Natural Resources High Risk/High Reward Program (grant no. 175026), the Arthropod and Nematode Biology and Management Program from the USDA Cooperative State Research, Education, and Extension Service (grant no. 2007-35302-18164), the Pests and Beneficial Species in Agricultural Production Systems from the USDA National Institute of Food and Agriculture (grant no. 2018-67014-28066), and the USDA National Institute of Food and Agriculture, Hatch Projects 1018010, 1018013, 0164681 , and 1003854.

The author(s) declare no conflict of interest.

\begin{abstract}
Until the early 1990s, cyst nematodes were abundant pathogens in fields where hosts of Heterodera spp. were frequent members of crop rotations along California's Central Coast. To mitigate damage caused by Heterodera schachtii and $H$. cruciferae, the soil fumigant 1,3 -dichloropropene $(1,3-D)$ was used by more than $43 \%$ of surveyed broccoli growers. Over the last few decades, use of 1,3-D and other nematicides has dramatically diminished, suggesting a decline in nematode disease pressure. The goal of this study was to examine the hypothesis that increased population densities of nematophagous fungi contribute to the low populations of Heterodera spp. in fields frequently cropped to their hosts. In 2016, soil samples were collected from 152 Brassica fields with a broad geographical distribution, from Santa Barbara County to Santa Cruz County. The average number of Heterodera cysts per $250 \mathrm{~cm}^{3}$ of soil ranged from 0.5 to 27.5 , with $62 \%$ of the soils harboring no detectable cyst nematodes and only a few samples reaching a potentially damaging threshold level. A baiting experiment with $H$. schachtii and cabbage was performed in a greenhouse to detect nematophagous fungi associated with nematode females as their posterior end emerged and became exposed to the soil's rhizosphere. An Illumina-based sequence analysis of these $H$. schachtii females identified several known nematophagous fungi, including members of the Hyalorbilia oviparasitica clade, Pochonia chlamydosporia, certain Fusarium spp., and others. These soils clearly harbor a diverse population of hyperparasitic fungi that could be biologically suppressing cyst nematodes below a damaging threshold.
\end{abstract}

Keywords: Hyalorbilia oviparasitica, Dactylella oviparasitica, Brachyphoris oviparasitica, Hyalorbilia aff. multiguttulata, sugarbeet cyst nematode, suppressive soils, biological control 
California is by far the largest U.S. producer of cole crops (USDA NASS 2020), with approximately two-thirds of them being grown in the fertile soils of its Central Coast, from Santa Barbara County to Santa Cruz County. Various cultivars of Brassica oleracea are grown, including broccoli, Brussels sprouts, cabbage, and cauliflower, among others (Johnson 1998). Many additional host crops of Heterodera spp. are also grown, such as spinach (Spinacia oleracea), table beets (Beta vulgaris), Swiss chard (Beta vulgaris subsp. vulgaris), and radish (Raphanus sativus). Also, mustards (Brassica juncea, B. napes, Sinapis alba) are often used as winter cover crops (Smith et al. 2011). All of these crops are hosts to either the sugarbeet (Heterodera schachtii) or the cabbage (H. cruciferae) cyst nematode, or both, and they are considered important vegetable pathogens. Indeed, H. schachtii has been reported to be among the most damaging plant-parasitic nematodes in the world (Jones et al. 2013; Sasser and Freckman 1987).

H. schachtii was most likely introduced to California from central Europe in the late 1800s via imported sugar beet seeds that were contaminated with nematode cysts (Cooke and Thomason 1978). For many decades, sugar beet production and processing were primarily concentrated along California's Central Coast, from the San Francisco Bay Area to Ventura County. Two sugar factories operated in this area, one in Salinas (Monterey County) and the other further south in Betteravia (Santa Barbara County). Over the years, it became less profitable to grow sugar beets compared to vegetables; a 9- to 10-month crop producing a relatively low-value commodity could not compete with two to three vegetable crops per year (S. Kaffka, personal communication).

When all sugarbeet production moved south to California's Imperial Valley, the coastal cyst nematode populations continued to thrive on susceptible host plants. Frequent plantings of these host crops resulted in a significant buildup of cyst nematode populations that caused considerable crop damage. Accordingly, use of the fumigant nematicide 1,3dichloropropene $(1,3-\mathrm{D})$ was quite common for the most profitable cole crops. Flint et al. (1992) reported that $43.2 \%$ of broccoli growers in Monterey County who were queried about their use of pesticides had used 1,3-D before its temporary withdrawal by the manufacturer in April 1990. This action was in response to the detection of high concentrations of this fumigant in the ambient air of a junior high school. This registration withdrawal led to predicted annual production losses of $\$ 15.7$ million for broccoli alone (Landels 1992). However, no overall adverse effect on cole crop yields was reported. For example, broccoli yield has steadily increased over the past 70 years by about $250 \mathrm{~kg} / \mathrm{ha}$ each year (Geisseler and Horwath 2016). In addition, when 1,3-D once again became available 6 years after the registration withdrawal, its use with most cole crops never reached previous levels. More strikingly, 1,3-D applications declined to negligible levels in subsequent years (CA-DPR 2019).

The goal of this study was to examine the hypothesis that nematophagous fungi contribute to the low populations of Heterodera spp. in Brassica field soils from California's Central Coast. The population densities of Heterodera spp. were determined in 152 soils cropped to Brassica spp. from this region. In addition, an Illumina-based ribosomal RNA (rRNA) internal transcribed spacer (ITS) sequence analysis was used to determine whether nematophagous fungi were associated with $H$. schachtii females derived from those soils using a baiting experiment.

\section{MATERIALS AND METHODS}

\section{Soil collection, processing, and initial nematode enumeration}

During the spring of 2016, soils from 152 cole crop fields were sampled from California's Central Coast, approximately from Santa Cruz to Lompoc. A composite soil sample from each location was shipped overnight to the University of California, Riverside, CA. After air drying in paper bags, the samples were sieved (about $4 \mathrm{~mm}$ aperture) and thoroughly mixed. To enumerate cyst nematodes, two separate $250-\mathrm{cm}^{3}$ subsamples were extracted by sieving and centrifugation (Dunn 1969). Cysts were counted using a dissecting microscope at $20 \times$ magnification. For each sample, five mature cysts were collected, placed into a $1.5-\mathrm{ml}$ microcentrifuge tube, and $500 \mu \mathrm{l}$ of a $2 \%$ commercial bleach solution was added to free the eggs from the gel matrix. The cysts were crushed with a mini plunger. The egg suspensions were well mixed, and $100 \mu \mathrm{l}$ was placed in a counting dish for enumeration. The counting step was performed twice.

\section{Nematode inoculum preparation}

$H$. schachtii was initially isolated from a parasitized sugar beet root, obtained from the USDA-ARS Desert Research Station, Brawley, CA. Nematode inoculum was reared by growing 4week-old cabbage (Brassica oleracea var. capitate 'Copenhagen Market Early') seedlings in steam-pasteurized sandy loam (approximately $75^{\circ} \mathrm{C}$ for $3 \mathrm{~h}$, Sanyo Laboratory Autoclave, Scientific Model MLS-3781L, Sanyo Electric Biomedical Division, Tokyo, Japan) infested with freshly hatched $H$. schachtii secondstage juveniles (J2). The plants were maintained in greenhouse pot cultures for approximately 3 months. Cysts were extracted as described above and placed on modified Baermann funnels (Flegg and Hooper 1970) containing $4 \mathrm{mM} \mathrm{ZnCl}_{2}$ to stimulate juvenile hatching. Hatched $H$. schachtii $\mathrm{J} 2$ were collected daily and stored in aerated water at $15 \pm 1^{\circ} \mathrm{C}$ for not more than $48 \mathrm{~h}$ before soil infestation. The numbers of $\mathrm{J} 2$ in the suspensions were determined using a stereomicroscope at $40 \times$ magnification.

\section{Greenhouse experiment for fungal baiting}

Each of the 152 soil samples was mixed with autoclaved sand $(1: 1 \mathrm{v} / \mathrm{v})$ to improve aeration and drainage. In previous research, the addition of $50 \%$ autoclaved sand did not significantly change the status of $H$. schachtii-suppressive soil (unpublished). Plastic cones (15 cm long $\times 2.5 \mathrm{~cm}$ diameter, Ray Leach Cone-tainers, Stuewe and Sons, Tangent, OR) were filled with about $250 \mathrm{~cm}^{3}$ of the soil mixes, leaving approximately $4 \mathrm{~cm}$ of headspace for watering. Three replicate cones were prepared. Cabbage (Copenhagen Market Early) seeds were incubated in a Petri dish containing moist tissue paper. After 1 week at $24 \pm 2^{\circ} \mathrm{C}$, each cone with soil was planted with one cabbage seedling. The cones were arranged in a hanging position in racks and incubated in a greenhouse at $26 \pm$ $2^{\circ} \mathrm{C}$. The seedlings were fertilized with liquid fertilizer (Miracle Gro 20-20-20, Scotts Company, Marysville, OH) every week. Four weeks after transplanting, approximately 1,000 H. schachtii $\mathbf{J} 2$ in $2 \mathrm{ml}$ of water were added to each cone $\left(\sim 4 \mathrm{~J} 2 / \mathrm{cm}^{3}\right.$ of soil). The cones were incubated at $26 \pm 2{ }^{\circ} \mathrm{C}$ for 10 weeks with ambient light, corresponding to approximately 1,260 degree-days calculated using a base temperature of $8^{\circ} \mathrm{C}$ for $\mathrm{H}$. schachtii (Curi and Zmoray 1966). From each replicate cone, 10 mature females were randomly collected from plant roots and stored in a $1.5-\mathrm{ml}$ microcentrifuge tube at $-80^{\circ} \mathrm{C}$ for DNA isolation. 
TABLE 1

Soils used in this study by crop, county, and densities of Heterodera cysts and eggs

\begin{tabular}{|c|c|c|c|c|c|c|c|}
\hline $\begin{array}{l}\text { Soil } \\
\text { no. }^{v}\end{array}$ & $\mathrm{Crop}^{\mathrm{w}}$ & $\begin{array}{l}\text { County locations } \\
\text { of the fields }\end{array}$ & $\begin{array}{l}\text { No. of Heterodera spp. cysts/eggs } \\
\text { per } 250 \mathrm{~cm}^{3} \text { of soil }\end{array}$ & $\begin{array}{l}\text { Soil } \\
\text { no. }^{\mathrm{v}}\end{array}$ & Crop $^{w}$ & $\begin{array}{l}\text { County locations } \\
\text { of the fields } \mathrm{s}^{\mathrm{x}}\end{array}$ & $\begin{array}{c}\text { No. of Heterodera spp. cysts/eggs } \\
\text { per } 250 \mathrm{~cm}^{3} \text { of soil }\end{array}$ \\
\hline$* 1$ & Kale & San Benito & 0 & $* 61$ & Broccoli & Monterey & 0 \\
\hline$* 2$ & Kale & San Benito & 0 & 62 & Broccoli & Monterey & 0 \\
\hline$* 3$ & Broccoli & Santa Cruz & $6.5 / 270.8$ & $* 63$ & Broccoli & Monterey & 0 \\
\hline$* 4$ & Red cabb. & Santa Cruz & 0 & 64 & Cauliflower & Monterey & $2.5 / 151.5$ \\
\hline$* 5$ & Broccoli & Santa Cruz & 0 & $* 65$ & Cauliflower & Monterey & $0.5 / 102.5$ \\
\hline$* 6$ & Cauliflower & Santa Cruz & 0 & $* 66$ & Cauliflower & Monterey & 0 \\
\hline$* 7$ & Broccoli & Monterey & 0 & 67 & Cauliflower & Monterey & $4 / 224.4$ \\
\hline 8 & Broccoli & Monterey & 0 & $* 68$ & Broccoli & Monterey & 0 \\
\hline$* 9$ & Broccoli & Monterey & 0 & $* 69$ & Broccoli & Monterey & 0 \\
\hline$* 10$ & Broccoli & Monterey & 0 & $* 70$ & Broccoli & Monterey & 0 \\
\hline$* 11$ & Broccoli & Monterey & 0 & $* 71$ & Cauliflower & Monterey & $1 / 148.1$ \\
\hline$* 12$ & Broccoli & Monterey & 0 & 72 & Cauliflower & Monterey & 0 \\
\hline$* 13$ & Cauliflower & Monterey & 0 & $* 73$ & Broccoli & Monterey & 0 \\
\hline$* 14$ & Broccoli & Monterey & 0 & $* 74$ & Cauliflower & Monterey & 0 \\
\hline$* 15$ & Broccoli & Monterey & 0 & $* 75$ & B. sprouts & Monterey & 0 \\
\hline$* 16$ & Broccoli & Monterey & 0 & $* 76$ & B. sprouts & Monterey & $2.5 / 281.7$ \\
\hline$* 17$ & Cauliflower & Monterey & 0 & $* 77$ & B. sprouts & Monterey & 0 \\
\hline 18 & Cauliflower & Monterey & 0 & *78 & B. sprouts & Monterey & $7.0 / 235.0$ \\
\hline$* 19$ & Broccoli & Monterey & 0 & $* 79$ & B. sprouts & Monterey & $11.0 / 351.8$ \\
\hline$* 20$ & Broccoli & Monterey & 0 & $* 80$ & B. sprouts & Monterey & $26.5 / 314.3$ \\
\hline 21 & Broccoli & Monterey & 0 & $* 81$ & B. sprouts & Monterey & $4.5 / 39.1$ \\
\hline$* 22$ & Broccoli & Monterey & 0 & $* 82$ & B. sprouts & Monterey & $0.5 / 65.0$ \\
\hline 23 & Cauliflower & Monterey & 0 & $* 83$ & Broccoli & Monterey & $4.5 / 95.6$ \\
\hline$* 24$ & Broccoli & Monterey & $1 / 149.4$ & $* 84$ & Broccoli & Monterey & $0.5 / 65.0$ \\
\hline$* 25$ & Cauliflower & Monterey & 0 & $* 85$ & Broccoli & Monterey & 0 \\
\hline 26 & Cauliflower & Monterey & 0 & $* 86$ & Broccoli & Monterey & $1 / 63.8$ \\
\hline 27 & Broccoli & Monterey & 0 & 87 & Cabbage & Monterey & 0 \\
\hline 28 & Broccoli & Monterey & 0 & 88 & Broccoli & Monterey & 0 \\
\hline$* 29$ & Broccoli & Monterey & 0 & $* 89$ & Broccoli & Monterey & $5 / 307.3$ \\
\hline$* 30$ & Broccoli & Monterey & 0 & $* 90$ & Cabbage & Monterey & 0 \\
\hline 31 & Cauliflower & Monterey & 0 & *91 & Broccoli & Monterey & 0 \\
\hline *32 & Broccoli & Monterey & 0 & $* 92$ & Broccoli & Monterey & $1 / 15.0$ \\
\hline$* 33$ & Cauliflower & Monterey & $0.5 / 88.8$ & 93 & Broccoli & Monterey & $1.5 / 146.9$ \\
\hline$* 34$ & B. sprouts & Monterey & 0 & 94 & Kale & San Benito & 0 \\
\hline *35 & Broccoli & Monterey & 0 & $* 95$ & Kale & Santa Clara & 0 \\
\hline$* 36$ & Broccoli & Monterey & 0 & $* 96$ & Broccoli & Santa Clara & 0 \\
\hline 37 & Cauliflower & Monterey & 0 & $* 97$ & Kale & Monterey & 0 \\
\hline *38 & Cauliflower & Monterey & $0.5 / 91.3$ & $* 98$ & Broccoli & Monterey & 0 \\
\hline *39 & Cauliflower & Monterey & $1.5 / 236.3$ & $* 99$ & Cabbage & Monterey & 0 \\
\hline 40 & Broccoli & Monterey & $0.5 / 58.8$ & $* 100$ & Broccoli & Monterey & 0 \\
\hline$* 41$ & Broccoli & Monterey & $1.5 / 158.1$ & *101 & Broccoli & Monterey & 0 \\
\hline$* 42$ & Cauliflower & Monterey & 0 & $* 102$ & B. sprouts & Monterey & 0 \\
\hline$* 43$ & Bok Choy & Monterey & 0 & $* 103$ & B. sprouts & Monterey & 0 \\
\hline 44 & Broccoli & Monterey & 0 & 104 & B. sprouts & Monterey & 0 \\
\hline$* 45$ & Broccoli & Monterey & $2 / 219.4$ & $* 105$ & Broccoli & S. Barbara & 1/93.8 \\
\hline 46 & Broccoli & Monterey & 0 & 106 & Broccoli & S. Barbara & $6.5 / 113.5$ \\
\hline$* 47$ & Broccoli & Monterey & $0.5 / 125.0$ & *107 & B. sprouts & S. Barbara & $2 / 248.1$ \\
\hline$* 48$ & Broccoli & Monterey & 0 & *108 & B. sprouts & S. Barbara & 0 \\
\hline 49 & Broccoli & Monterey & 0 & *109 & Cauliflower & S. Barbara & $7.5 / 149.8$ \\
\hline 50 & Broccoli & Monterey & 0 & $* 110$ & B. sprouts & S. Barbara & $3 / 215.4$ \\
\hline$* 51$ & Broccoli & Monterey & 0 & $* 111$ & Broccoli & S. Barbara & $8 / 326.8$ \\
\hline$* 52$ & Cauliflower & Monterey & 0 & 112 & Broccoli & S. Barbara & $3 / 312.3$ \\
\hline$* 53$ & B. sprouts & Monterey & 0 & $* 113$ & Cauliflower & S. Barbara & 0 \\
\hline 54 & Cauliflower & Monterey & $14.5 / 229.0$ & $* 114$ & Broccoli & S. Barbara & $0.5 / 98.8$ \\
\hline$* 55^{\mathrm{z}}$ & Broccoli & Monterey & 0 & 115 & Cauliflower & Monterey & $0.5 / 223.8$ \\
\hline$* 56$ & Broccoli & Monterey & 0 & *116 & Broccoli & Monterey & $4.5 / 150.6$ \\
\hline$* 57$ & Broccoli & Monterey & 0 & 117 & Broccoli & Monterey & $1 / 98.8$ \\
\hline$* 58^{\mathrm{z}}$ & Broccoli & Monterey & 0 & *118 & Broccoli & Monterey & $1 / 98.8$ \\
\hline 59 & Broccoli & Monterey & $1 / 30.0$ & $* 119$ & Broccoli & Monterey & $4 / 117.5$ \\
\hline$* 60^{\mathrm{z}}$ & Cauliflower & Monterey & 0 & *120 & Broccoli & Monterey & $\begin{array}{c}0 \\
\text { (Continued on next page) }\end{array}$ \\
\hline
\end{tabular}

${ }^{\mathrm{v}}$ Asterisks (*) indicate soils used in the fungal analysis of Heterodera schachtii females.

${ }^{\mathrm{w}}$ B. sprouts $=$ Brussels sprouts; and Red cabb. $=$ red cabbage.

${ }^{\times}$S. Barbara $=$Santa Barbara; and S.L. Obispo $=$San Luis Obispo.

${ }^{y}$ Average values.

${ }^{\mathrm{z}}$ Soils not used for the fungal community analyses of the $H$. schachtii females because of low fungal rRNA ITS sequence counts (see Materials and Methods). 
TABLE 1

(Continued from previous page)

\begin{tabular}{|c|c|c|c|c|c|c|c|}
\hline $\begin{array}{l}\text { Soil } \\
\text { no. }\end{array}$ & Crop $^{w}$ & $\begin{array}{l}\text { County locations } \\
\text { of the fields }{ }^{\mathrm{x}}\end{array}$ & $\begin{array}{c}\text { No. of Heterodera spp. cysts/eggs } \\
\text { per } 250 \mathrm{~cm}^{3} \text { of soil }\end{array}$ & $\begin{array}{l}\text { Soil } \\
\text { no. }\end{array}$ & Crop $^{w}$ & $\begin{array}{l}\text { County locations } \\
\text { of the fields }{ }^{\mathrm{x}}\end{array}$ & $\begin{array}{c}\text { No. of Heterodera spp. cysts/eggs } \\
\text { per } 250 \mathrm{~cm}^{3} \text { of soil } \mathrm{l}^{\mathrm{y}}\end{array}$ \\
\hline$* 121$ & Broccoli & Monterey & 0 & $* 137$ & Cauliflower & S. Barbara & $27.5 / 327.5$ \\
\hline$* 122$ & Broccoli & Monterey & 0 & $* 138$ & B. sprouts & S. Barbara & $18.5 / 276.3$ \\
\hline$* 123$ & Broccoli & Monterey & 0 & 139 & Cauliflower & S. Barbara & 0 \\
\hline *124 & Broccoli & Monterey & 0 & $* 140$ & Cauliflower & S. Barbara & $1 / 49.4$ \\
\hline$* 125$ & Broccoli & Monterey & 0 & $* 141$ & Broccoli & S. Barbara & $18.5 / 251.0$ \\
\hline *126 & Broccoli & Monterey & $5.5 / 125.5$ & 142 & Broccoli & S. Barbara & $7 / 115.0$ \\
\hline *127 & Broccoli & Monterey & $7.0 / 140.0$ & $* 143$ & Red cabb. & S. Barbara & $7 / 132.3$ \\
\hline$* 128$ & Broccoli & S. Barbara & 0 & *144 & Cauliflower & S. Barbara & 0 \\
\hline$* 129$ & Broccoli & S. Barbara & $9.0 / 307.8$ & *145 & Broccoli & S. Barbara & 0 \\
\hline$* 130$ & Cauliflower & S.L. Obispo & $3.0 / 124.1$ & $* 146$ & Broccoli & S. Barbara & $9.0 / 159.5$ \\
\hline$* 131$ & Broccoli & S.L. Obispo & 0 & $* 147$ & Cauliflower & S. Barbara & $1.5 / 126.3$ \\
\hline$* 132$ & Broccoli & S.L. Obispo & $2.0 / 96.3$ & $* 148$ & Broccoli & S. Barbara & 0 \\
\hline$* 133$ & Broccoli & S.L. Obispo & $0.5 / 155.0$ & *149 & Broccoli & S. Barbara & $10.5 / 246.5$ \\
\hline$* 134$ & Broccoli & S.L. Obispo & $7.5 / 87.8$ & 150 & Cauliflower & S. Barbara & $10.5 / 329.3$ \\
\hline$* 135$ & Broccoli & S.L. Obispo & 0 & 151 & Cabbage & S. Barbara & $2.5 / 166.9$ \\
\hline *136 & Broccoli & S. Barbara & $4.5 / 137.8$ & $* 152$ & Cabbage & S. Barbara & $3.5 / 370.0$ \\
\hline
\end{tabular}

\section{DNA isolation from $H$. schachtii females}

DNA was isolated from $H$. schachtii females that were collected from plant roots at the end of the baiting experiment. Thirty-two of the 152 soils were not used in this analysis because of an insufficient number $(<10)$ of $H$. schachtii females. This usually occurred because at least two plants in the three replicate cones grew poorly or died. For each of the remaining 119 soils, DNA was isolated from one of the replicate samples of $10 \mathrm{H}$. schachtii females. The nematode females were first washed three times with $500 \mu \mathrm{l}$ of sterile water, and then DNA was isolated using the DNeasy PowerSoil Kit (Qiagen, Germantown, MD) with a 150-s bead-beating step using a Mini-Beadbeater-16 (BioSpec), but using the bead tubes (Matrix A) from the FastDNA Soil Kit (MP Biomedicals, Irvine, CA).

\section{Illumina fungal rRNA ITS library construction and sequencing}

Illumina fungal rRNA ITS libraries were constructed as follows. Polymerase chain reactions (PCRs) were performed using a DNA Engine thermal cycler (Bio-Rad, Hercules, CA) and 25- $\mu$ l reactions containing Phusion High-Fidelity DNA Polymerase Mix (New
England Biolabs, Ipswich, MA) supplemented with $500 \mu \mathrm{g} / \mathrm{ml}$ of bovine serum albumin, $1 \mathrm{mM} \mathrm{MgCl}_{2}, 250 \mu \mathrm{M}$ of each deoxynucleotide triphosphate (dNTP), $400 \mathrm{nM}$ of each primer, and $2.5 \mu \mathrm{l}$ of DNA template. The PCR primers gITS7 (GTGARTCATC GARTCTTTG) and ITS4 (TCCTCCGCTTATTGATATGC) targeted the ITS2 region of the ribosomal rRNA gene operon (Ihrmark et al. 2012; White et al. 1990), with the reverse primers including 12-base barcodes, and both primers including the Illumina sequences needed for cluster formation. Thermal cycling parameters were $94^{\circ} \mathrm{C}$ for $5 \mathrm{~min} ; 35$ cycles of $94^{\circ} \mathrm{C}$ for $20 \mathrm{~s}, 56^{\circ} \mathrm{C}$ for $20 \mathrm{~s}$, and $72^{\circ} \mathrm{C}$ for $30 \mathrm{~s}$; followed by $72^{\circ} \mathrm{C}$ for $10 \mathrm{~min}$. PCR products were purified using a QIAquick PCR Purification Kit (Qiagen) according to the manufacturer's instructions, and libraries were constructed using an equal amount (ng) of each sample. DNA sequencing (single-end 300 base) was performed using an Illumina MiSeq.

\section{Illumina fungal rRNA ITS sequence data processing}

The UPARSE pipeline was used for demultiplexing, length trimming, quality filtering, and operational taxonomic unit (OTU) picking using default parameters or recommended guidelines that were initially described in Edgar (2013) and that have been updated at https://www.drive5.com/usearch/manual/uparse_pipeline.html.
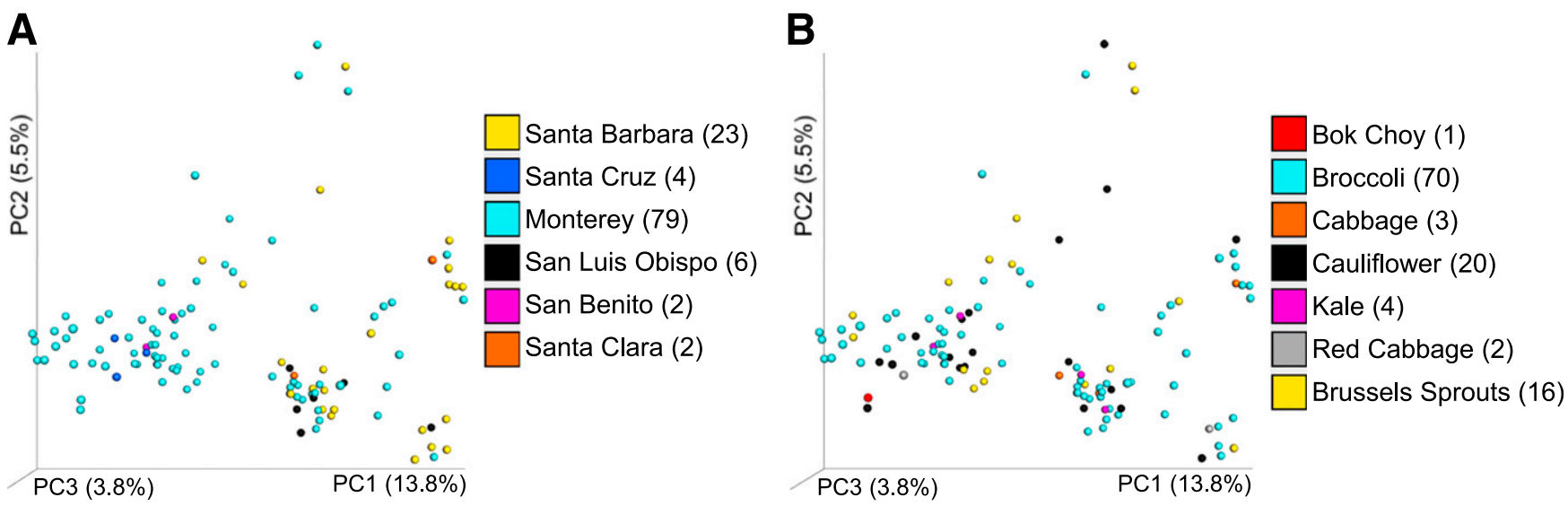

FIGURE 1

Fungal community analysis of Heterodera schachtii females derived from soils cropped to Brassica species and produced by a baiting experiment: A, county analyses; and B, crop analyses. Beta diversity distance values were generated from fungal rRNA ITS sequences and displayed using principal coordinates analysis. Values in parentheses after county and crop are the number of replicate samples. 
Briefly, after demultiplexing and using the recommended 1.0 expected error threshold, sequences were trimmed to a uniform length of 297 bases. Sequences were then dereplicated and clustered into zero-radius OTUs using the UNOISE3 algorithm
(Edgar 2016), which detects and removes chimeric sequences. An amplicon sequence variant (ASV) table was then generated using the otutab command. Taxonomic assignments of the fungal ASVs were performed using the RDP Classifier version 2.12

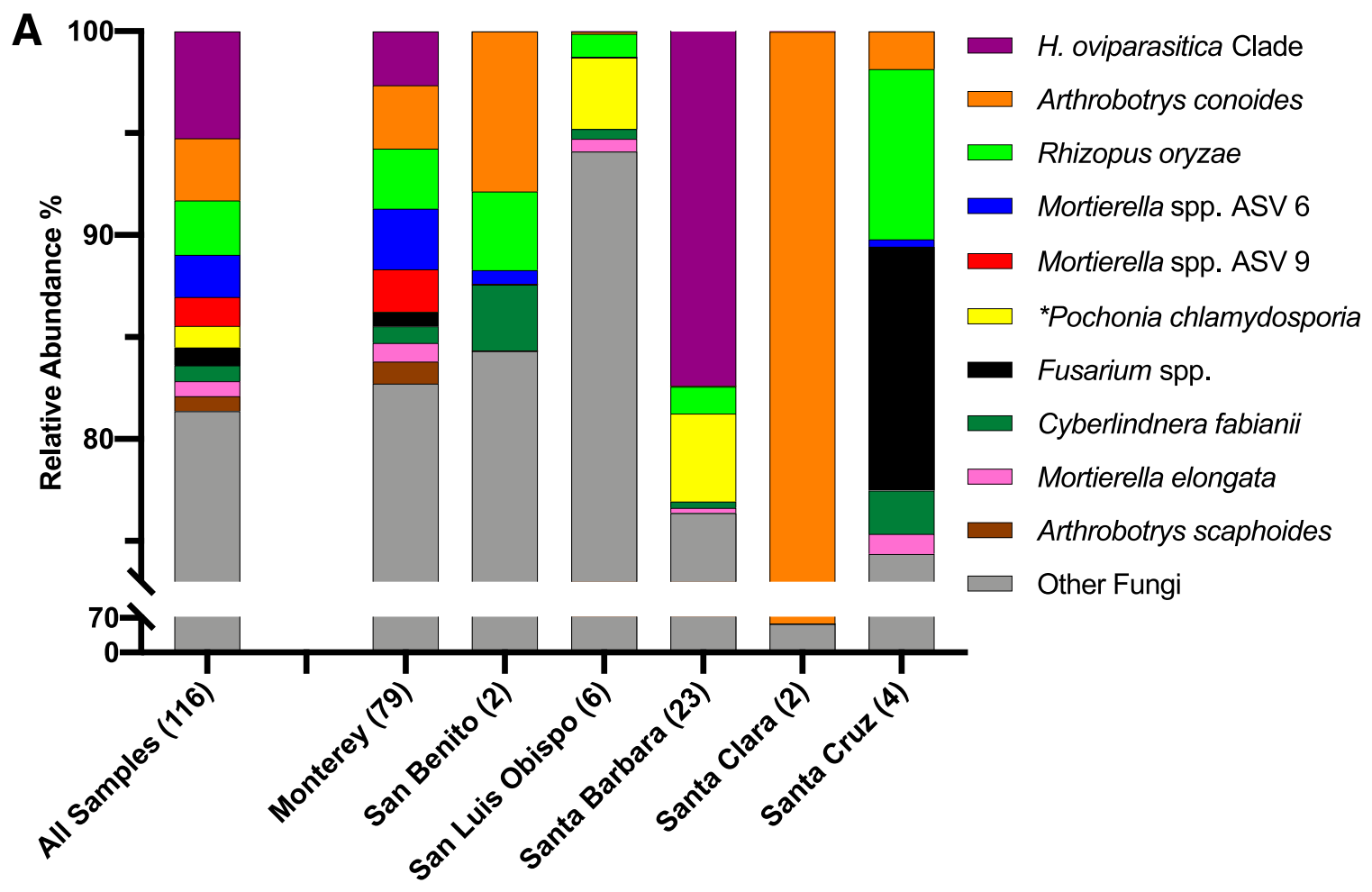

B
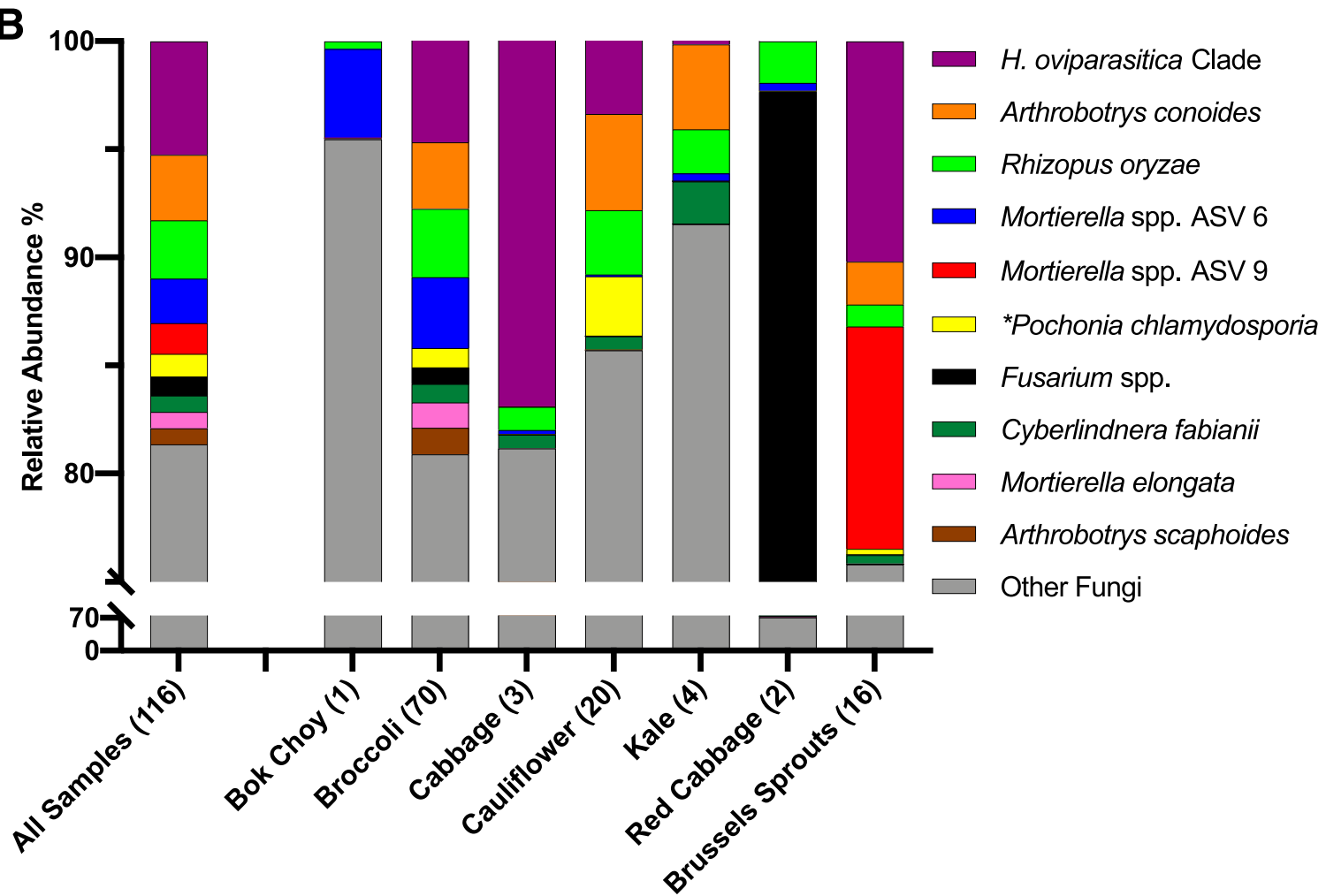

FIGURE 2

Fungal species associated with Heterodera schachtii females derived from soils cropped to Brassica species and produced by a baiting experiment: A, county analyses; and B, crop analyses. Average relative abundances were determined by an examination of fungal rRNA ITS sequences. Asterisk ( $\left(^{*}\right)$ indicates this phylotype had more than one best match, and therefore its taxonomic assignment is not definitive. Other fungi are all of the taxa with less than $0.74 \%$ relative abundance combined. The number of replicate samples is shown in parentheses. 
(Wang et al. 2007), trained on the ver8_99_s_02.02.2019 release of the UNITE database (Kõljalg et al. 2013), and ASVs having nonfungal assignments were removed. Because the fungal sequence counts from the nematodes derived from three of the 119 soils were low $(<668)$, they were removed from further analysis.

The fungal rRNA ITS sequences have been deposited in the National Center for Biotechnology Information (NCBI) Sequence Read Archive under BioProject accession number PRJNA638436.

\section{Illumina fungal rRNA ITS sequence analyses}

QIIME (Caporaso et al. 2010) was used to calculate abundance Jaccard beta diversity distance matrices, which were depicted using principal coordinates analysis and were statistically assessed using Adonis PERMANOVA tests. Statistical differences among the taxa were determined using edgeR and the false discovery rate method (Benjamini and Hochberg 1995; McCarthy et al. 2012; Robinson et al. 2010). Prism was used to make the fungal species plots (GraphPad, La Jolla, CA).

\section{Phylogenetic tree construction}

The phylogenetic tree was constructed using fungal rRNA ITS sequences with high identity to members of the $H$. oviparasitica clade (Smith Becker et al. 2020) that were identified by this study (Brassica ASVs) and by a related study examining soils cropped to sugar beets (Sugar Beet ASVs) (Witte et al. 2020), as well as from nematophagous fungi belonging to the $H$. oviparasitica clade (Olatinwo et al. 2006b; Stirling and Mankau 1978; Timper and Riggs 1998; Yin et al. 2003) and related fungi described in Baral et al. (2018).

The phylogenetic tree was constructed by performing the following analyses using GenomeNet (https://www.genome.jp/). Sequences were aligned using the CLUSTAL W algorithm (Thompson et al. 1994). The final alignment had a length of 273 nucleotides, and the sequences ranged from 184 to 261 nucleotides. Alignment and phylogenetic reconstructions were performed using the function "build" of ETE3 v3.0.0b32 (HuertaCepas et al. 2016) as implemented on the GenomeNet (https:// www.genome.jp/tools/ete/). Maximum likelihood trees were inferred using RAxML v8.1.20, which was run with model

\section{TABLE 2}

Statistical analysis of the relative abundances of the fungal species associated with the Heterodera schachtii females by county and obtained from a baiting experiment ${ }^{\mathrm{z}}$

\begin{tabular}{lcc}
\hline Taxa & Monterey (79) & Santa Barbara (23) \\
\hline Hyalorbilia oviparasitica clade & $2.64 \mathrm{a}$ & $17.41 \mathrm{~b}$ \\
Arthrobotrys conoides & $3.12 \mathrm{a}$ & $0.02 \mathrm{~b}$ \\
Rhizopus oryzae & 2.94 & 1.33 \\
Mortierella spp. ASV 6 & $2.98 \mathrm{a}$ & $0.00 \mathrm{~b}$ \\
Mortierella spp. ASV 9 & $2.09 \mathrm{a}$ & $0.00 \mathrm{~b}$ \\
*Pochonia chlamydosporia & $0.03 \mathrm{a}$ & $4.30 \mathrm{~b}$ \\
Fusarium spp. & $0.68 \mathrm{a}$ & $0.00 \mathrm{~b}$ \\
Cyberlindnera fabianii & 0.80 & 0.31 \\
Mortierella elongata & 0.92 & 0.26 \\
Arthrobotrys scaphoides & $1.09 \mathrm{a}$ & $0.00 \mathrm{~b}$ \\
\hline
\end{tabular}

${ }^{\mathrm{z}}$ Numbers in the cells are mean relative abundance. For each row, means followed by a different letter are significantly different (edgeR analyses, false discovery rate-adjusted $P$ values $<0.05$ ). The number of replicate samples is shown in parentheses after county. Asterisk (*) indicates this phylotype had more than one best match, and thus its taxonomic assignment is not definitive.
GTRGAMMA and the default parameters (Stamatakis 2014). Branch supports were computed out of 100 bootstrapped trees. The tree figure was created using the Interactive Tree of Life (Letunic and Bork 2007) (https://itol.embl.de/).

The Illumina fungal rRNA ITS sequences from this study with high identity to those from the $H$. oviparasitica clade, and that were included in this phylogenetic analysis, have been deposited in the NCBI under the accession numbers MT248325, MT248326, MT248327, MT248328, MT248329, MT248330, MT248331, MT248332, and MT573527.

\section{RESULTS AND DISCUSSION}

\section{Soils examined}

Soils from 152 fields cropped to Brassica species along California's Central Coast were examined. These soils came from fields primarily cropped to broccoli and that had a broad geographical distribution, from Santa Barbara County to Santa Cruz County (Table 1).

\section{Population densities of Heterodera spp.}

The average number of Heterodera spp. cysts per $250-\mathrm{cm}^{3}$ of soil ranged from 0.5 to 27.5 , with $62 \%$ of the soils harboring no detectable cysts and only a few samples reaching a potentially damaging threshold level of $12 \mathrm{eggs} / \mathrm{g}$ of soil (Abawi and Mai 1980) (Table 1). These low values support the hypothesis that many of the soils in this region suppress Heterodera spp. despite their originally widespread occurrence and frequent cropping to host plants of these nematodes.

\section{Identifying fungi associated with $\boldsymbol{H}$. schachtii females using a baiting experiment}

The baiting experiment enabled the identification of fungi associated with $H$. schachtii females, an important stage of nematode development, increasing the likelihood of identifying nematophagous fungi. This experiment involved planting a

\section{TABLE 3}

Statistical analysis of the relative abundances of the fungal species associated with the Heterodera schachtii females by crop and obtained from a baiting experiment ${ }^{\mathrm{z}}$

\begin{tabular}{lccc}
\hline Taxa & Broccoli (70) & B. sprouts (16) & Cauliflower (20) \\
\hline H. oviparasitica & 4.68 & 10.20 & 3.36 \\
A. conoides & 3.09 & 1.97 & 4.46 \\
Rhizopus oryzae & 3.15 & 1.02 & 2.95 \\
Mortierella ASV 6 & $3.28 \mathrm{a}$ & $0.00 \mathrm{~b}$ & 0.10 \\
Mortierella ASV 9 & $0.00 \mathrm{a}$ & $10.28 \mathrm{bc}$ & $0.00 \mathrm{c}$ \\
*. chlamydosporia & 0.89 & 0.27 & 2.75 \\
Fusarium spp. & $0.77 \mathrm{a}$ & $0.00 \mathrm{~b}$ & $0.00 \mathrm{~b}$ \\
C. fabianii & 0.85 & 0.41 & 0.63 \\
M. elongata & $1.17 \mathrm{a}$ & $0.02 \mathrm{~b}$ & $0.00 \mathrm{~b}$ \\
A. scaphoides & $1.23 \mathrm{a}$ & $0.00 \mathrm{~b}$ & $0.01 \mathrm{~b}$ \\
\hline
\end{tabular}

${ }^{\mathrm{z}}$ Numbers in the cells are mean relative abundance. For each row, means followed by a different letter are significantly different (edgeR analyses, false discovery rate-adjusted $P$ values $<0.05$ ). The number of replicate samples is shown in parentheses after crop. Asterisk (*) indicates this phylotype had more than one best match, and thus its taxonomic assignment is not definitive. B. sprouts = Brussels sprouts; $H$. oviparasitica $=$ Hyalorbilia oviparasitica clade; Mortierella ASV 6= Mortierella spp. ASV 6; Mortierella ASV 9= Mortierella spp. ASV 9; P. chlamydosporia = Pochonia chlamydosporia; $C$. fabianii = Cyberlindnera fabianï; $M$. elongata $=$ Mortierella elongata $;$ and $A$. scaphoides $=$ Arthrobotrys scaphoides. 
H. schachtii host crop (cabbage) in these soils, infesting the soils with $H$. schachtii $\mathrm{J} 2$, and then collecting nematode females from the plant roots after two nematode generations. Only 119 of these soils produced a sufficient number of $H$. schachtii females for further analysis, primarily because of poor plant growth or seedling diseases that were present in the other 33 soils.

\section{Fungal community and species analysis of $\boldsymbol{H}$. schachtii females derived from soils cropped to Brassica species}

An Illumina-based sequence analysis of the rRNA ITS region was used to examine the fungal communities associated with $H$. schachtii females that were produced by the baiting experiment. Nematode samples from three of the 119 soils were removed from further analysis because of low numbers of fungal sequences. Statistical analyses were only performed on sample types with more than six replicate samples.

A beta diversity analysis showed that the fungal communities associated with the $H$. schachtii females were distinct in Monterey and Santa Barbara Counties (PERMANOVA test $P=$ 0.001) (Fig. 1A). A similar beta diversity analysis determined that there were no differences in the fungal communities among the different crop types (Fig. 1B, PERMANOVA test $P>0.05$ ).

To examine the relative abundance of the fungal species associated with the $H$. schachtii females from the baiting experiment, taxonomic plots were constructed using the fungal rRNA ITS sequence data. The most abundant fungi associated with the $H$. schachtii females included at least five nematophagous species or genera including members of the $H$. oviparasitica clade, Arthrobotrys conoides, Pochonia chlamydosporia, Fusarium spp., Mortierella spp., and Arthrobotrys scaphoides (Fig. 2, all samples).

There were clear differences in the relative abundances of the nematode-associated fungal species between both the counties and the crops (Fig. 2). The statistical analyses (Tables 2 and 3) showed that there were higher relative abundances of the $H$. oviparasitica clade and $P$. chlamydosporia in $H$. schachtii females derived from soils in Santa Barbara County than from soils in Monterey County. Conversely, A. conoides was found in higher abundances in Monterey County than in Santa Barbara County. Mortierella spp. ASV 6 and 9 were most abundant in Monterey County and in fields cropped to broccoli and Brussels sprouts, respectively. Fusarium spp. and A. scaphoides were most abundant in Monterey County and in fields cropped to broccoli. Mortierella elongata was most abundant in fields cropped to broccoli.

These results are consistent with the hypothesis that increased population densities of nematophagous fungi contribute to low populations of Heterodera spp. in fields cropped to Brassica species along California's Central Coast. Fungi that are both known parasites of $H$. schachtii females and that were abundant enough to impact cyst nematode populations included members of the H. oviparasitica clade (Olatinwo et al. 2006a, 2006b; Smith Becker et al. 2020), Pochonia chlamydosporia (Kerry and Bourne 1996; Kerry et al. 1993), and certain Fusarium spp. (Chen and Chen 2002; Chen et al. 1994; Gao et al. 2008; Jorgenson 1970; Westphal and Becker 2001). Given that the relative abundances of these three nematode-associated fungi are different between the two counties, this suggests that this putative nematode population suppressiveness may be caused by different

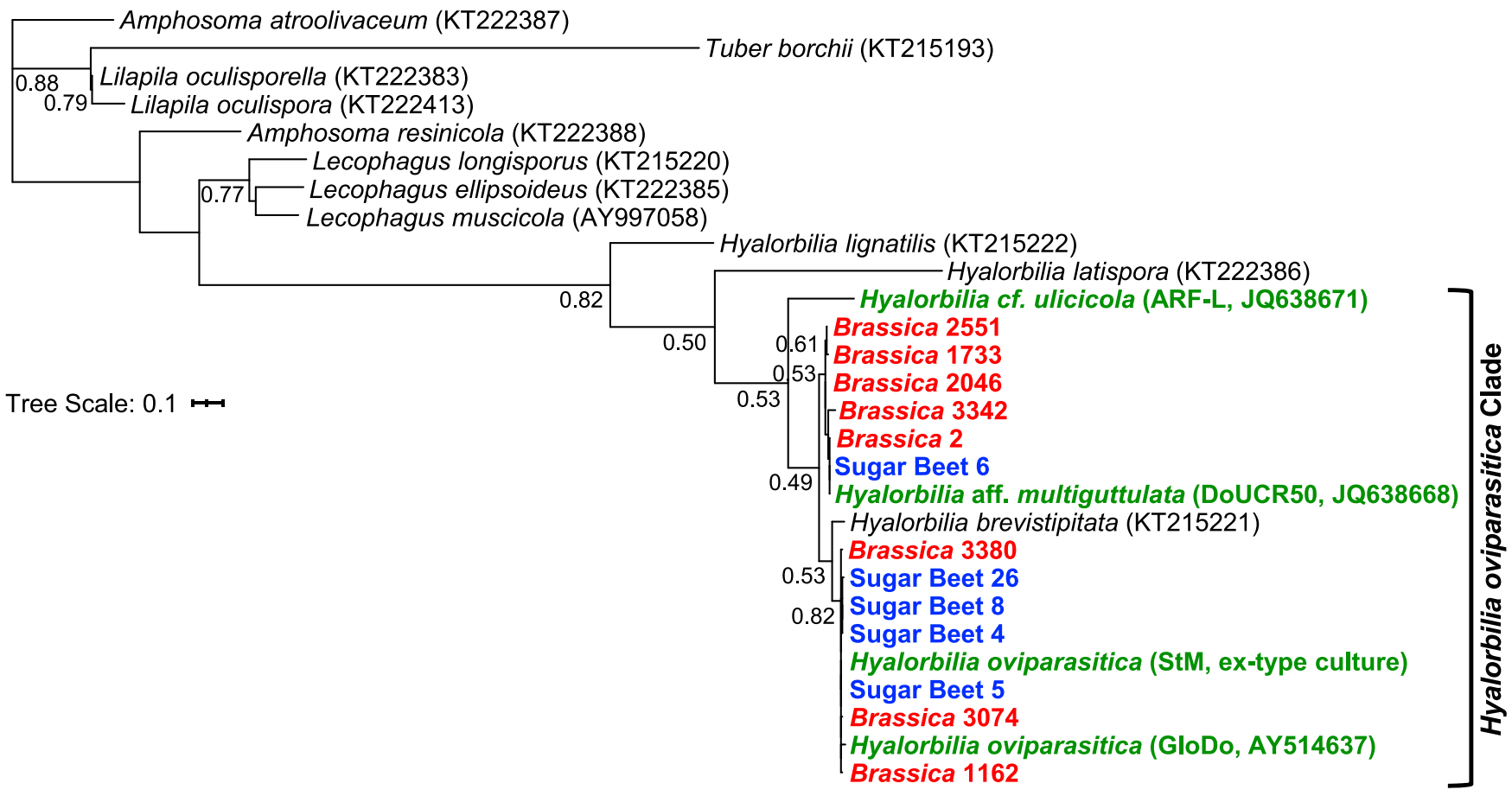

FIGURE 3

Phylogenetic relationships of nematophagous fungi and related members of the Orbiliomycetes. The tree was constructed by performing a maximum-likelihood analysis of fungal rRNA ITS sequences obtained from four cultured nematophagous fungi, related phylotypes obtained by culture-independent analyses, and members of the Orbiliomycetes. Fungal phylotypes from culture-independent analyses of Heterodera schachtii females derived from soils cropped to (i) Brassica species (this study) and (ii) sugar beets (Witte et al. 2020) are indicated by Brassica followed by an ASV number and Sugar Beet followed by an ASV number, respectively. The outgroup is Tuber borchii. Bootstrap values (out of 100) are shown on the branches if $\geq 0.50$. Branch lengths are the expected number of substitutions per nucleotide. Additional information for Hyalorbilia oviparasitica StM is ATCC 38908, CBS 379.84, and MH861748, and for H. oviparasitica GloDo it is CBS 347.85. Additional information for Hyalorbilia aff. multiguttulata DoUCR50 is JQ638668. 
organisms and/or combinations of organisms. However, because members of the $H$. oviparasitica clade had the highest relative abundance when all 116 samples were examined (Fig. 2), this suggests that this group of fungi might play the most important role. In addition, although the relative abundances of members of the $H$. oviparasitica clade and $P$. chlamydosporia did not vary among the crops, Fusarium spp. were highest in broccoli.

The other fungal species shown in Figure 2 and Tables 2 and 3 were likely associated with the females as spores or propagules but unable to attack the female stage of the nematode; trapping fungi in particular likely fall into this group. Their relatively high abundance in this analysis might be related to the fact that many of these species produce abundant conidia.

\section{Phylogenetic analysis of the fungi identified in this study in relation to nematophagous fungi and other members of the Orbiliomycetes}

Next, a phylogenetic analysis was performed to examine the relationships among the fungal sequences identified by this study that had high sequence identity to $H$. oviparasitica (formerly Dactylella oviparasitica and Brachyphoris oviparasitica, Smith Becker et al. 2020) and related fungi (Fig. 3). This analysis shows a coherent assemblage of organisms and phylotypes composed of four nematophagous fungi (green text), sequences from this study (red text), sequences from a similar study examining $H$. schachtii females derived from soils cropped to sugar beets (blue text) (Witte et al. 2020), and H. brevistipitata. This group was called the $H$. oviparasitica clade.

The fungal rRNA ITS sequences obtained from the two cultureindependent studies, designated by either Sugar Beet or Brassica and an ASV number, are posited to come from nematophagous fungi because of their placement in the $H$. oviparasitica clade (Fig. 3 ) and because they were found in the analyses of $H$. schachtii females. In addition, given that the sequences from these two studies are intermingled in the $H$. oviparasitica clade, it appears that these fungi are not crop specific. This is consistent with prior research that showed that $H$. aff. multiguttulata DoUCR50 (Smith Becker et al. 2020) was attracted to emerging nematode females but not to plant roots (Smith Becker et al. 2013).

The presence of $H$. brevistipitata in the $H$. oviparasitica clade is intriguing because it suggests that this fungus might be nematophagous. However, because $H$. brevistipitata was originally isolated in its teleomorphic state from decaying plant material (Liu et al. 2005), its nematophagous status is unknown.

\section{CONCLUSIONS}

The results presented in this study are consistent with the hypothesis that indigenous members of the $H$. oviparasitica clade contribute to the low populations of Heterodera spp. in Brassica field soils from California's Central Coast. Other research supporting this hypothesis includes the discovery that a member of the $H$. oviparasitica clade was responsible for the $H$. schachtii suppressiveness in field $9 \mathrm{E}$ at the University of California Riverside's Agricultural Operations (Olatinwo et al. 2006b). In addition, several strains of fungi in the $H$. oviparasitica clade (ARF or Arkansas Fungus) (Yang et al. 2012), which were isolated from parasitized soybean cyst nematodes ( $H$. glycines) from a suppressive soil, were able to reduce the population densities of this nematode when amended to a conducive soil (Kim and Riggs 1995; Timper and Riggs 1998). Finally, in greenhouse experiments, the amount of $H$. schachtii suppressiveness was positively associated with the initial population densities of a member of the H. oviparasitica clade (Yang et al. 2012).

Taken together, the interpretation of these data leads to the conclusion that fungi belonging to the $H$. oviparasitica clade, which appear to be globally distributed (Yang et al. 2012), could be reducing the populations of several species of cyst nematodes that detrimentally impact a wide variety of economically important crops. In addition, similar to take-all decline in wheat, in which monoculture leads to the suppression of take-all disease (Cook and Baker 1983), the frequent cropping of Heterodera host crops in soils from California's Central Coast is speculated to lead to an increase in fungi that are suppressing these cyst nematodes. Because the results presented in this paper are only associations, they will need to be followed up by experiments that isolate these fungi and then test them by adding them to soil in nematode population suppression assays.

\section{LITERATURE CITED}

Abawi, G. M., and Mai, W. F. 1980. Effects of initial population densities of Heterodera schachtii on yield of cabbage and table beets in New York State. Phytopathology 70:481-485.

Baral, H. O., Weber, E., Gams, W., Hagedorn, G., Liu, B., Liu, X. Z., Marson, G., Marvanova, L., Stadler, M., and Weiss, M. 2018. Generic names in the Orbiliaceae (Orbiliomycetes) and recommendations on which names should be protected or suppressed. Mycol. Prog. 17:5-31.

Benjamini, Y., and Hochberg, Y. 1995. Controlling the false discovery rate: A practical and powerful approach to multiple testing. J. R. Stat. Soc. B 57: 289-300.

CA-DPR. 2019. California Department of Pesticide Regulation's (DPR) Pesticide Use Report (PUR) System. https://www.cdpr.ca.gov/docs/pur/ purmain.htm.

Caporaso, J. G., Kuczynski, J., Stombaugh, J., Bittinger, K., Bushman, F. D., Costello, E. K., Fierer, N., Peña, A. G., Goodrich, J. K., and Gordon, J. I. 2010. QIIME allows analysis of high-throughput community sequencing data. Nat. Methods 7:335-336.

Chen, F. J., and Chen, S. Y. 2002. Mycofloras in cysts, females, and eggs of the soybean cyst nematode in Minnesota. Appl. Soil Ecol. 19:35-50.

Chen, S., Dickson, D. W., Kimbrough, J. W., McSorley, R., and Mitchell, D. J. 1994. Fungi associated with females and cysts of Heterodera glycines in a Florida soybean field. J. Nematol. 26:296-303.

Cook, R. J., and Baker, K. F. 1983. The Nature and Practice of Biological Control of Plant Pathogens. APS Press, St. Paul, MN.

Cooke, D. A., and Thomason, I. J. 1978. Distribution of Heterodera schachtii in California. Plant Dis. Rep. 62:989-993.

Curi, J., and Zmoray, I. 1966. Beziehung klimatischer Faktoren zur Entwicklungsdauer von Heterodera schachtii in der Slowakei (CSSR). Helminthologia Bratisl. 7:49-63.

Dunn, R. A. 1969. Extraction of cysts of Heterodera species from soils by centrifugation in high density solutions. J. Nematol. 1:7.

Edgar, R. C. 2013. UPARSE: Highly accurate OTU sequences from microbial amplicon reads. Nat. Methods 10:996-998.

Edgar, R. C. 2016. UNOISE2: Improved error-correction for Illumina 16S and ITS amplicon sequencing. bioRxiv. https://doi.org/10.1101/081257.

Flegg, J. J. M., and Hooper, D. J. 1970. Extraction for free-living stages from soil Pages 5-22 in: Laboratory Methods for Working with Plant and Soil Nematodes. J. F. Southey, ed. Her Majesty's Stationery Office, London, U.K.

Flint, M. L., Davidson, N. A., Zalom, F. G., and Auburn, J. S. 1992. Potential losses of pesticides in California and identification of alternative pest management practices in broccoli. Am. Entomol. (Lanham Md.) 38:115-121.

Gao, X., Yin, B., Borneman, J., and Becker, J. O. 2008. Assessment of parasitic activity of Fusarium strains obtained from a Heterodera schachtii-suppressive soil. J. Nematol. 40:1-6.

Geisseler, D., and Horwath, W. R. 2016. Broccoli production in California https://apps1.cdfa.ca.gov/FertilizerResearch/docs/Broccoli_Production_ CA.pdf.

Huerta-Cepas, J., Serra, F., and Bork, P. 2016. ETE 3: Reconstruction, analysis, and visualization of phylogenomic data. Mol. Biol. Evol. 33: 1635-1638.

Ihrmark, K., Bödeker, I. T., Cruz-Martinez, K., Friberg, H., Kubartova, A., Schenck, J., Strid, Y., Stenlid, J., Brandström-Durling, M., and Clemmensen, K. E. 2012. New primers to amplify the fungal ITS2 regionevaluation by 454-sequencing of artificial and natural communities. FEMS Microbiol. Ecol. 82:666-677. 
Johnson, A. W. 1998. Vegetable crops. Pages 595-635 in: Plant-Nematode Interactions. G. A. Pederson, G. L. Windham, and K. R. Barker, eds. Agronomy Society of America, Madison, WI.

Jones, J. T., Haegeman, A., Danchin, E. G., Gaur, H. S., Helder, J., Jones, M. G., Kikuchi, T., Manzanilla-Lopez, R., Palomares-Rius, J. E., Wesemael, W. M., and Perry, R. N. 2013. Top 10 plant-parasitic nematodes in molecular plant pathology. Mol. Plant Pathol. 14:946-961.

Jorgenson, E. C. 1970. Antagonistic interaction of Heterodera schachtii Schmidt and Fusarium oxysporum (Woll.) on sugarbeets. J. Nematol. 2:393-398.

Kerry, B. R., and Bourne, J. M. 1996. The importance of rhizosphere interactions in the biological control of plant parasitic nematodes-A case study using Verticillium chlamydosporium. Pestic. Sci. 47:69-75.

Kerry, B. R., Kirkwood, I. A., de Leij, F. A. A. M., Barba, J., Leijdens, M. B., and Brookes, P. C. 1993. Growth and survival of Verticillium chlamydosporium Goddard, a parasite of nematodes, in soil. Biocontrol Sci. Technol. 3:355-365.

Kim, D. G., and Riggs, R. D. 1995. Efficacy of the nematophagous fungus ARF18 in alginate-clay pellet formulations against Heterodera glycines. J. Nematol. 27:602-608.

Kõljalg, U., Nilsson, R. H., Abarenkov, K., Tedersoo, L., Taylor, A. F., Bahram, M., Bates, S. T., Bruns, T. D., Bengtsson-Palme, J., Callaghan, T. M., Douglas, B., Drenkhan, T., Eberhardt, U., Duenas, M., Grebenc, T., Griffith, G. W., Hartmann, M., Kirk, P. M., Kohout, P., Larsson, E., Lindahl, B. D., Lucking, R., Martin, M. P., Matheny, P. B., Nguyen, N. H., Niskanen, T., Oja, J., Peay, K. G., Peintner, U., Peterson, M., Poldmaa, K., Saag, L., Saar, I., Schussler, A., Scott, J. A., Senes, C., Smith, M. E., Suija, A., Taylor, D. L., Telleria, M. T., Weiss, M., and Larsson, K. H. 2013. Towards a unified paradigm for sequence-based identification of fungi. Mol. Ecol. 22:5271-5277.

Landels, S. P. 1992. Assessment of economic impacts on growers of Telone's unavailability in California and information base for market reentry. SRI Project 3242. SRI International, Health and Performance Chemicals Center, Palo Alto, CA.

Letunic, I., and Bork, P. 2007. Interactive tree of life (iTOL): An online tool for phylogenetic tree display and annotation. Bioinformatics 23:127-128.

Liu, B., Liu, X.-Z., and Zhuang, W.-Y. 2005. A new species of Hyalorbilia and its anamorph from China. Nova Hedwigia 81:145-156.

McCarthy, D. J., Chen, Y., and Smyth, G. K. 2012. Differential expression analysis of multifactor RNA-Seq experiments with respect to biological variation. Nucleic Acids Res. 40:4288-4297.

Olatinwo, R., Becker, J. O., and Borneman, J. 2006a. Suppression of Heterodera schachtii populations by Dactylella oviparasitica in four soils. J. Nematol. 38:345-348.

Olatinwo, R., Yin, B., Becker, J. O., and Borneman, J. 2006b. Suppression of the plant-parasitic nematode Heterodera schachtii by the fungus Dactylella oviparasitica. Phytopathology 96:111-114.

Robinson, M. D., McCarthy, D. J., and Smyth, G. K. 2010. edgeR: A bioconductor package for differential expression analysis of digital gene expression data. Bioinformatics 26:139-140.

Sasser, J. N., and Freckman, D. W. 1987. A world perspective on Nematology: The role of the society. Pages 7-44 in: Vistas on Nematology.
J. A. Veech and D. W. Dickson, eds. Society of Nematologists, Hyattsville, MD

Smith, R., Bugg, R. L., and Daugovish, O. 2011. Botany and species selection. Pages 5-16 in: Cover Cropping for Vegetable Production: A Grower's Handbook. R. Smith, R. Bugg, O. Daugovish, M. Gaskell, and M. Van Horn, eds. Publication 3517. University of California, Division of Agriculture and Natural Resources, Davis, CA.

Smith Becker, J., Borneman, J., and Becker, J. O. 2013. Dactylella oviparasitica parasitism of the sugar beet cyst nematode observed in trixenic culture plates. Biol. Control 64:51-56.

Smith Becker, J., Borneman, J., and Becker, J. O. 2020. Effect of Heterodera schachtii female age on susceptibility to three fungal hyperparasites in the genus Hyalorbilia. J. Nematol. 52:1-12.

Stamatakis, A. 2014. RAxML version 8: A tool for phylogenetic analysis and post-analysis of large phylogenies. Bioinformatics 30:1312-1313.

Stirling, G. R., and Mankau, R. 1978. Dactylella oviparasitica, a new fungal parasite of Meloidogyne eggs. Mycologia 70:774-783.

Thompson, J. D., Higgins, D. G., and Gibson, T. J. 1994. CLUSTAL W: Improving the sensitivity of progressive multiple sequence alignment through sequence weighting, position-specific gap penalties and weight matrix choice. Nucleic Acids Res. 22:4673-4680.

Timper, P., and Riggs, R. D. 1998. Variation in efficacy of isolates of the fungus $\mathrm{ARF}$ against the soybean cyst nematode Heterodera glycines. J. Nematol. 30:461-467.

USDA NASS. 2020. Vegetables 2019 Summary February 2020. https:// www.nass.usda.gov/Publications/Todays_Reports/reports/vegean20.pdf.

Wang, Q., Garrity, G. M., Tiedje, J. M., and Cole, J. R. 2007. Naive Bayesian classifier for rapid assignment of rRNA sequences into the new bacterial taxonomy. Appl. Environ. Microbiol. 73:5261-5267.

Westphal, A., and Becker, J. O. 2001. Components of soil suppressiveness against Heterodera schachtii. Soil Biol. Biochem. 33:9-16.

White, T. J., Bruns, T., Lee, S., and Taylor, J. 1990. Amplification and direct sequencing of fungal ribosomal RNA genes for phylogenetics. Pages 315-322 in: PCR Protocols: A Guide to Methods and Applications. M. A. Innis, D. H. Gelfand, J. J. Sninsky, and T. J. White, eds. Academic Press, San Diego, CA.

Witte, H., Yang, J.-i., Logan, G. D., Colindres, N. B., Peacock, B. B., Smith Becker, J., Ruegger, P. M., Becker, J. O., and Borneman, J. 2020. Hyalorbilia oviparasitica clade detected in field soils cropped to sugar beets and enriched in the presence of Heterodera schachtii and a host crop. PhytoFrontiers 1. doi: 10.1094/PHYTOFR-07-20-0005-R.

Yang, J. I., Benecke, S., Jeske, D. R., Rocha, F. S., Smith Becker, J., Timper, P., Becker, J. O., and Borneman, J. 2012. Population dynamics of Dactylella oviparasitica and Heterodera schachtii: Toward a decision model for sugar beet planting. J. Nematol. 44:237-244.

Yin, B., Valinsky, L., Gao, X., Becker, J. O., and Borneman, J. 2003. Identification of fungal rDNA associated with soil suppressiveness against Heterodera schachtii using oligonucleotide fingerprinting. Phytopathology 93:1006-1013. 